\title{
Direito À SAÚde E PROBLEMÁtica DOS AGROTÓXICOS ${ }^{*}$
}

\author{
HEALTH LAW AND AGROCHEMICAL TROUBLES
}

Helita Barreira Custódio(**)

\section{RESUMO}

A partir de esclarecimentos sobre as noções de meio ambiente, saúde e agrotóxicos e do Direito como conjunto de princípios e normas de conduta social, definem-se as noções de Direito Agrário, Direito Sanitário e Direito Ambiental como novos ramos do Direito e os princípios e normas constitucionais aplicáveis, notadamente em matéria de competência e de conciliação do desenvolvimento sócio-econômico com a preservação da sadia qualidade ambiental propícia à vida. São apresentadas as normas legais e regulamentares sobre Direito Agrário (com as respectivas diretrizes sobre alimentos agrotóxicos) e Direito Sanitário. Discute-se o Direito à saúde e a problemática dos agrotóxicos no Brasil e os deveres e responsabilidades do Poder Público e da coletividade para cumprir, adequar, atualizar e aplicar as normas sobre agrotóxicos integrantes do Sistema Jurídico brasileiro. Conclui-se que é necessário maior rigor na fiscalização, inspeção e aplicação de agrotóxicos, o reexame do art. 10 da Lei n. 8.080, de 19-9-90, a revisão redacional da ementa e das normas dos arts. $1^{\circ}$ e $8^{\circ}$ da Lei n. 9.294 , de 15-7-96, e a reabertura de novos debates, junto ao Congresso Nacional e ao Poder Executivo, para os fins de reapreciação e restabelecimento das normas do art. 57 do Projeto de Lei n. 1.164/91 (transformado na Lei $n$. 9.605, de 12-2-98).

(*) Palestra perante o SEMINÁRIO sobre "AGRICULTURA, SAÚDE E MEIO AMBIENTE", promovido pela COMISSÃO DO MEIO AMBIENTE da OAB-SP, na qualidade de expositora do tema "AGROTÓXICOS: Abastecimento x Meio Ambiente" (adaptado ao presente, de forma harmônica com a matéria ali prevista, com as revisōes e atualizações necessárias), realizado no Salão Nobre da OAB-SP, Praça da Sé, 385, São Paulo-SP, em 30-11-1999.

(**) Doutora em Direito e Professora "Livre-Docente" pela USP; Aperfeiçoamento em Administração Pública, com especialização em Direito Urbanístico, pela Universidade de Roma "LA SAPIENZA"; Longa experiência como Procuradora do Município de São Paulo; ex-Advogada da CETESB-SP; exAssessora Judiciária do STF (Brasília-DF); Membro da CPPU/PREF/SP; Membro Emérito da Comissão do Meio Ambiente da OAB-SP; Membro do Centro de Estudos e Pesquisas de Direito Sanitário (órgão científico de apoio da FSP/USP); Vice-Presidente da Sociedade Brasileira de Direito do Meio Ambiente. 


\section{Palavras-chave}

Direito à saúde, direito ambiental, agrotóxicos.

\section{ABSTRACT}

Starting from explanations on the environment, health and toxic agrochemical notions and of Law as a group of beginnings and norms of social conduct, the notions of Agrarian Law, Health Law and Environmental Law are defined as new branches of Law and the beginnings and applicable constitutional norms, especially as regards to competence and of conciliation of the socioeconomic development with the preservation of the healthy favorable environmental quality to the life are also defined. The legal norms and bylaws on Agrarian Law (with the respective guidelines on victuals toxic agrochemicals) and on Sanitary Law are presented. Health Law and health problems related to toxic agrochemicals in Brazil and the duties and responsibilities of the Public Power and of the collectivity to accomplish, to adapt, to update and to apply the Brazilian Juridical System norms on toxic agrochemicals are discussed. It concludes that there is larger necessity of rigidity in the inspection and application of toxic agrochemicals, that the art. 1 st of the Lav no. $8.080 / 90$ should be re-examined, that the revision of the ementa and of the norms of the arts. 1st and 8th of the Law no. 9.294/ 96 must be done and that it is necessary the re-opening of new debates, at the National Congress and at the Executive Power, for the re-establishment of the norms of the art. 57 of the bill no. 1.164/91 (transformed in the Law no. 9.605/98).

\section{Key words}

Health law, environmental law, toxic agrochemicals.

\section{INTRODUÇÃO}

Em breve nota introdutória, para melhor compreensão do abrangente, relevante e atual tema sobre Direito à Saúde e Problemática dos Agrotóxicos (na agricultura, nos alimentos e bebidas em geral, no meio ambiente), direta e indiretamente relacionado com a Política Agrícola, a Política Sanitária e a Política Ambiental, tornam-se convenientes breves noções, de forma especial, sobre meio ambiente, com seus variados recursos ambientais (naturais, sociais, culturais) ecologicamente equilibrados e indispensáveis à vida, saúde em seus diversos valores relacionados com a conservação da vida, o bem-estar da pessoa humana e conseqüentemente da sociedade, bem como agrotóxicos como perigosas e preocupantes fontes de poluição de efeitos danosos ao meio ambiente, à saúde pública e à vida. 
a) Noções de meio ambiente. Em princípio, a noção de meio ambiente, para os fins protecionais, é muito ampla, abrangendo todos os bens ou recursos naturais e artificiais de valor juridicamente protegido, desde o solo, as águas, o ar, a flora, a fauna, as belezas naturais e artificiais, o ser humano, ao patrimônio histórico, artístico, turístico, paisagístico, monumental, arqueológico, além das variadas disciplinas urbanísticas contemporâneas ${ }^{(1)}$. Considera-se meio ambiente humano o "conjunto das condições naturais e sociais em que vive a pessoa humana e que são suscetiveis de influenciar a sua existência"(2). "O meio ambiente é, assim, a interação do conjunto de elementos naturais, artificiais e culturais que propiciem o desenvolvimento equilibrado da vida humana"(3). Em seu amplo sentido, o meio ambiente "é tudo aquilo que nos cerca", é "um direito para cada pessoa humana"(4), dentre outras harmônicas noções doutrinárias.

A nosso ver, por força dos diversos elementos componentes do patrimônio ambiental e das leis naturais e humanas correspondentes, ampla é a noção do meio ambiente. Em princípio, considera-se meio ambiente o conjunto tanto de circunstâncias e de relações recíprocas reguladas pelas leis naturais de ordem física, química e biológica como de fatores sócio-econômico-culturais disciplinados pelas leis humanas integrantes do Direito Positivo, que, de forma vinculada e interdependente, assegura condições favoráveis de existência, desde a concepção, a germinação ou qualquer outra circunstância originária ao nascimento, ao desenvolvimento, à preservação e à continuidade da vida saudável, em seus diversos ciclos normais evolutivos, da pessoa humana e dos demais seres vivos (animais, vegetais e microorganismos em geral). Trata-se de oportuna noção didático-científica, de conteúdo global, abrangendo todos os bens ou recursos ambientais, tanto os naturais (vivos e não vivos, ar, águas em geral, fauna, flora, solo com seu subsolo, alimentos, luz solar, energia, silêncio ambiental), típicos do meio ambiente natural, como os sociais (relacionados com as atividades sócio-econômicas, políticas, agricola-urbanísticas, industriais, habitacionais, profissionais, sanitárias, espirituais, educacionais, recreativas, de transportes) e os bens culturais (compreendidos todos os bens de valor cultural, materiais e imateriais, integrantes do patrimônio cultural) típicos do meio ambiente humano, caracterizados por interações ou inter-relações com outros meios e por progressiva integração ajustável às novas exigências sociais de cada monumento, de forma compatível com os princípios do Direito

(1) P. Salvatore, Tutela Pubblica dell'Ambiente, in Rassegna Semestrale dell'Unione Nazionale Avvocati degli Enti Pubblici, Roma, 1975, p. 343. V. nossa tese: Autonomia do Municipio na Preservação Ambiental, São Paulo, Resenha Universitária, 1976, pp. 1 e s.

(2) Guido Colombo, Dizionario di Urbanistica, Milano, Pirola, 1981, p. 12.

(3) Jose Afonso da Silva, Direito Urbanístico Brasileiro. São Paulo, RT, 1981, p. 435.

(4) Amedeo Postiglione, Manuale dell'Ambiente - Guida alla Legislazione Ambientale, La Nuova Italia Scientifica - NIS, Roma, 1986, p. 16. 
Ambiental, em defesa e preservação do meio ambiente saudável e indispensável à qualidade ambiental propícia à vida em todas as suas formas e à saúde pública.

Como defin ição legal, "entende-se por meio ambiente: o conjunto de condições, leis, irfluências e interações de ordem física, química e biológica, que permite, abriga e rege a vida em todas as suas formas", considerando-se, ainda, o "rneio ambiente como um patrimônio público a ser necessariamente assegurado e protegido, tendo em vista o uso coletivo" (Lei n. 6.938 , de 31.8 .81 arts. $3^{\circ}, 1$, e $\left.2^{\circ}, 1\right)$. Trata-se de ampla definição legal, pois atinge "tudo aquilo que permite a vida, que a abriga e rege", abrangendo "as comunidades, os ecossistemas e a biosfera"(5).

A Constituição brasileira, consagrando os princípios e as normas da legislação ambiental, define, expressamente, o meio ambiente saudável ou ecologicamente equilibrado como direito de todos, considerado bem de uso comum do povo e essencial à sadia qualidade de vida (como condição indispensável à saúde pública), impondo-se ao Poder Público (União, Estados, Distrito Federal e Municípios) e à coletividade (todas as pessoas físicas e jurídicas, estas de direito privado com ou sem fins lucrativos) o dever de defendê-lo e preservá-lo para as presentes e futuras gerações (C, art. 225). O meio ambiente saudável, definido expressamente na vigente Magna Carta, constitui novo e relevante direito subjetivo, expressamente assegurado e garantido pela vigente Constituição (direito objetivo) a todas as pessoas, físicas ou jurídicas, conferindo legitimação para agir (dever e não mera faculdade) tanto às pessoas jurídicas de direito público e de direito privado como às pessoas físicas ou cidadãos individualmente considerados, pelos meios processuais próprios, em defesa do meio ambiente lesado ou ameaçado de lesão, sempre de forma vinculada à defesa da saúde pública e da vida, como direitos fundamentais invioláveis.

b) Noções cle saúde. Do latim salus (conservação da vida), o termo saúde, em seu sentido originário, vernáculo ou jurídico, designa o estado de saúde, ou o estaclo de sanidade dos seres viventes. Saúde pública é a expressão usada para indicar o estado de sanidade da população de um país, de uma região, de uma zona ou de uma cidade ${ }^{(6)}$. Em seu amplo sentido jurídico, em princípio, considera-se saúde um bem público de interesse nacional, caracterizado como o estado de pleno bem-estar físico ou biológico, psíquico ou mental, social (em seus diversos aspectos educacionais, econômicos, familiares, espirituais, morais), cultural e ambiental da pessoa humana, individual, coletiva e publicamente considerada. Em resumo, a saúde

(5) Paulo Affonso Leme Machado, Direito Ambiental Brasileiro, São Paulo, RT, 1982, p. 4; já na $8^{a}$ ed., São Paulo, Malheiros, 2000.

(6) De Plácido e Silva, Vocabulário Jurídico, 9ª ed., Rio de Janeiro, Forense, 1986, vols. II e IV, p. 174. 
constitui um bem público constitucionalmente assegurado, garantido e protegido ao pleno bem-estar de todos. Em razão das desafiantes e abrangentes questões contemporâneas relacionadas com a saúde, trata-se de noção vinculada a um complexo de harmônicas ações prioritárias, permanentes e preventivas, ajustáveis ao equilibrado estado de salubridade ambiental, em progressivas condições favoráveis à promoção, à proteção, à recuperação e à melhoria da saúde pública e à conservação da vida.

No Direito Comparado, dentre outros países, evidencia-se que tanto o Direito Ambiental italiano ${ }^{(7)}$ como o Direito Ambiental francês ${ }^{(8)}$ vêm progressivamente ampliando e vinculando as noções notadamente de saúde, meio ambiente e agricultura, com expressas e rigorosas normas sobre a luta contra a poluição em todas as suas formas, a contaminação dos alimentos, das águas e das bebidas em geral por agrotóxicos, produtos químicos, aditivos, substâncias perigosas em geral, alimentos produzidos por meio de organismos geneticamente modificados (alimentos transgênicos) e a obrigatória menção nas etiquetas correlatas; contra a poluição por lixos (hospitalares, químicos, radioativos, tóxicos em geral), a poluição sonora ou por ruídos em geral; a luta em prol das medidas preventivas contra riscos de danos ambientais; medidas higiênicas, de vigilância sanitária, de saneamento básico, junto às atividades sanitárias, agrícolas, urbanísticas, construtivas, ambientais, industriais, recreativas e outras medidas sanitárias próprias para proteger e preservar o meio ambiente saudável e, conseqüentemente, proteger e preservar a saúde humana e a vida.

No Direito Internacional, perante a Organização Mundial da Saúde, observa-se a ampliação do conceito de saúde, diante do aumento e agravamento dos prejudiciais efeitos contrários decorrentes de atividades, condutas ou procedimentos perigosos que possam ocasionar dano não só ao estado físico ou psíquico da pessoa humana, mas também a qualquer realidade da vida social, como a segurança, a tranqüilidade, a liberdade, a igualdade, a propriedade, o trabalho, a educação, enfim, toda causa ou efeito prejudicial ao bem-estar do cidadão em sociedade, individual, coletiva ou publica-

(7) IL CODICE DELL'AMBIENTE (coordenação de Stefano Maglia e Maurizio Santoloci, Piacenza, La Tribuna, 1989), contendo, além das normas do Direito Ambiental, disposições gerais e especiais do Direito Agrário, de fertilizantes, substâncias perigosas e aditivos, de alimentos e bebidas, com a obrigatória e clara informação nas embalagens, nas etiquetas ou nos rótulos, dano ambiental por poluição em todas as suas formas, residuos em geral, instalações nucleares, dentre outras, bem como do Direito Sanitário (texto único das leis sanitárias e da instituição do Serviço Sanitário Nacional).

(8) CODE DE L'ENVIRONNEMENT - Protection de la Nature - Lutte contre les nuisances (Sixième edition, Paris, Dalloz, 1998), compreendendo, além das normas do Direito Ambiental, disposições gerais e especiais do Código Rural, de Urbanismo, de luta contra os danos por poluição sonora, por resíduos, por instalações nucleares, do ar, das águas, por fertilizantes ou produtos químicos ou fertilizantes na agricultura, por organismos geneticamente modificados, por raios ionizantes, dentre outras, bem como do Código da Saúde Pública, além de uma parte dedicada às disposições de ordem preventiva (PRÉVENTION DES RISQUES MAJEURS), pp. 1705 e s. 
mente considerado, diante dos progressivos fenômenos danosos, notadamente da poluiçâio ambiental. Assim, superado o conceito tradicional e condicionado à falta de enfermidades, em razão da contínua gravidade e ampliação das "moléstias de civilização", considera-se saúde, para os fins de proteção contra as condutas lesivas, dentre outras, ao meio ambiente, "o estado de completo bem-estar físico, mental e social, e não apenas a ausência de molétias $€$ e enfermidades"(9).

Sob esse aspecto, a AGENDA 21 introduz relevantes diretrizes sobre a "Proteção e Promoção das Condições da Saúde Humana", diante das científicas evidências, segundo as quais a "saúde e o desenvolvimento estão intimamente relacionados". Nesta progressiva evolução conceitual, tornou-se patente a consaggração da ampla noção de "saúde ambiental", vinculada a ações e serviços de promoção, proteção, recuperação e melhoria da qualidade ambiental indispensável à saúde de todas as pessoas, individual, coletiva e publicamente consideradas, com a inclusão da saúde dos trabalhadores, dos índios e demais comunidades ou grupos tanto das zonas rurais como das desafiantes zonas urbana e periférica. A proteção da saúde ambiental se vincula a permanentes informação ambiental e educação ambiental, de forma integracla com a educação sanitária, a educação agrícola, a educação alimentar, a educação urbanística, a educação econômica, a educação científico-tecnológica, em todos os setores da sociedade, para a conscientização pública, sęgundo a qual defender o meio ambiente saudável é defender a saúde ambiental, no interesse de todos. Conscientiza-se de que os "vínculos existentes entre saúde e melhorias ambientais e sócio-econômicas exigem esforços intersetoriais", mediante planejamento cooperativo realizado pelos diversos níveis de Governo, organizações não-governamentais e comunidades lociais, para reforçar as atividades em defesa e preservação da saúde ambiental ou da saúde da população, com a especial inclusão de programas preventivos à eliminação ou redução dos riscos para a saúde decorrentes da poluição e dos perigos ambientais em qualquer de suas formas (poluição do ar em locais abertos ou fechados, poluição das águas, dos solos, por pesticidas ou agrotóxicos em geral na agricultura, nos alimentos e nas bebidas em geral, a poluição sonora, as radiações ionizantes, os efeitos da radiação ultravioleta em conseqüência da diminuição da camada estratosférica de ozônio) (Cap. 6, c/c os Caps. 14, 19, 20, 21, 22).

A vigente Cionstituição nacional, de forma compatível com as normas internacionais e com suas próprias normas notadamente de ordem econômica (política urbana, política agrícola), social, ambiental, educacional, cul-

(9) J. P. Charbonneau e M. Rodes, Ecologia social, in Enciclopédia de Ecologia, São Paulo, E.P.U. EDUSP, 1979, pp. 423 e 433. Nesse sentido, reporta-se às considerações do Prof. Guido F. S. Soares, O Direito Internacional Sanitário e seus Temas: Apresentaçāo de sua Incômoda Vizinhança, in Revista de Direito Sanitário, v. 1, n. 1, São Paulo, LTr, CEPEDISA, NAP-DISAUSP, 2000, pp. 49, 64 e s. 
tural, científico-tecnológica, introduz relevantes normas de Direito Sanitário (norma agendi) e estabelece que: "A saúde é direito de todos e dever do Estado", garantido mediante políticas sociais e econômicas, vinculadas a políticas sanitárias, agrícolas, urbanísticas, ambientais, com prioridade para as atividades preventivas, que visem à redução do risco de doença e de outros agravos e ao acesso universal e igualitário às ações e aos serviços para sua promoção, proteção, recuperação e melhoria (C, art. 196, c/c os arts. 198, 200). Considerados de "relevância pública", uma vez que se referem à saúde como bem público constitucional e legalmente protegido, as ações e os serviços públicos de saúde devem ser executados diretamente pelo Poder Público, ou através de terceiros por pessoas físicas ou jurídicas de direito privado, todos com as competências, os deveres e as responsabilidades expressa e constitucionalmente previstos (C, arts. 196 a 200, c/c os

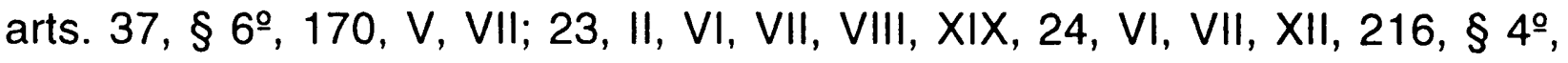
$220, \S 3^{\circ}, I I, \S 4^{\circ}, 225$, § $1^{\circ}$, IV, V, VI, VII, §§ $\left.2^{\circ}, 3^{\circ}\right)$.

A Lei n. 8.080, de 19-9-90, em observância às determinações dos arts. 197 e 200 da Constituição Federal, dispondo sobre as condições para a promoção, proteção e recuperação da saúde, a organização e o funcionamento dos serviços correspondentes, regula, em todo o território nacional, as ações e os serviços de saúde, executados, isolada e conjuntamente, em caráter permanente ou eventual, por pessoas naturais e jurídicas de direito público ou privado (art. $\left.1^{\circ}\right)^{(10)}$. A referida Lei define a saúde como "um direito fundamental do ser humano, devendo o Estado prover as condições indispensáveis ao seu pleno exercício" (art. $2^{\circ}$ ). O dever do Estado de garantir a saúde, mediante a formulação e a execução de políticas sócio-econômicas preventivas à redução de riscos de doenças e de outros agravos, bem como o estabelecimento de condições asseguradoras de acesso universal e igualitário às ações e aos serviços para a sua promoção, proteção e recuperação, não exclui o dever das pessoas, da família, das empresas e da sociedade (art. $\left.2^{\circ}, \S \S 1^{\circ}, 2^{\circ}\right)$. Dentre os fatores determinantes e condicionantes da saúde, destacam-se: a alimentação, a moradia, o saneamento básico, o meio ambiente saudável, o trabalho, a educação, o transporte, o lazer, o acesso

(10) Adverte-se a inconstitucionalidade da expressão "ou eventual" da norma do art. $1^{\circ}$ da Lei em exame, uma vez que as ações e os serviços públicos de saúde, executados por pessoas físicas ou juridicas de direito público ou privado. constituem dever constitucional, em caráter prioritário, permanente e preventivo, de forma integral, em qualquer circunstância de efetivas enfermidades ou de medidas preventivas contra riscos de doenças ou de outros danos, por força da vigente Constituição (arts. 196, 197, II), sem qualquer alternativa ou facultativa opção discricionária de eventualidade ali não existente. Evidentemente, a flagrante incompatibilidade da expressão "ou eventual" da norma do art. $1^{\circ} \mathrm{em}$ apreço com a obrigatória norma constitucional, em efetivo e iminente prejuizo contra a saúde da população, além de sujeitar-se à ação direta de inconstitucionalidade (C, art. $102,1, a$ ), impõe a imediata revisão da norma do art. $1^{\circ}$ da Lei n. 8.080, de 19-9-90, perante o Congresso Nacional, para os fins da inadiável supressão da viciada e inconciliável expressão "ou eventual", após a compativel expressão "em caráter permanente" ali prevista e que deve permanecer. 
outras afins ou similares pela vigente Constituição (art. $220, \S 4^{\circ}$, c/c os arts. $\left.200, \mathrm{I}, \mathrm{VII}, 225, \S 1^{\circ} \mathrm{N}, \mathrm{V}, \mathrm{VII}\right)$, reafirmou-se e ampliou-se o conceito legal de agrotóxicos e afin:s, a partir da Lei federal n. 7.802, de 11-7-89, segundo a qual se consideram "agrotóxicos e afins: a) os produtos e os agentes de processos físicos, químicos ou biológicos, destinados ao uso nos setores de produção, no armazenamento e beneficiamento de produtos agrícolas, nas pastagens, na proteção de florestas, nativas ou implantadas, e de outros ecossistemas e também de ambientes urbanos, hídricos e industriais, cuja finalidade seja alterar a composição da flora ou da fauna, a fim de preserválas da ação danosia de seres vivos considerados nocivos; b) substâncias e produtos, empregados como desfolhantes, dessecantes, estimuladores e inibidores de crescimento". Consideram-se "componentes" de tais agrotóxicos e afins "os princípios ativos, os produtos técnicos, suas matérias-primas, os ingredientes inertes e aditivos usados na fabricação de agrotóxicos e afins" (Lei n. 7.802, de 11-7-89, art. 2o, I e II (Decs. Regulamentares n. 98.816, de 11-1-90; n. 99.657, de 26-10-90; n. 991, de 24-11-93; n. 3.550, de 27-72000), com as alterações da Lei n. 9.974, de 6-6-2000, bem como as complementações das Leis n. 9.294, de 15-7-96, n. 10.167, de 27-12-2000, no tocante às restriçcies legais ao uso e à propaganda, dentre outros produtos, dos "defensivos agrícolas", previstas no $\S 4^{\circ}$ do art. 220 , da vigente Constituição) $)^{(15)}$.

Sem qualquer pretensão de esgotar as abrangentes questões integrantes das noções de meio ambiente, saúde e agrotóxicos, reconhecidamente complexas, relevantes e em contínua evolução, evidencia-se a manifesta importância das básicas, harmônicas e conexas idéias, cada vez mais oportunas às reais informações e revisões, aos necessários conhecimentos in-

(15) Observa-se que, não obstante a consagração da adequada expressão "agrotóxicos" na norma constitucional do art. $220, \S 4^{9}$, a Lei federal n. 9.294, de 15-7-96, estabelecendo normas sobre a propaganda comercial correlata, em vez de adotá-la como determina a Técnica Legislativa, usa a criticada e enganosa expressão "defensivos agricolas", não aceita pela comunidade científico-juridica, uma vez que não se trata de produtos de defesa da agricultura, mas, sim, de graves impactos sobre o meio ambiente, a agricultura, a saúde da população e a segurança da sociedade, conforme as advertências e denuncias da autorizada doutrina cientifica já demonstradas. A substituição da científica e adequada Expressão "agrotóxicos", constitucionalmente consagrada, lógica e compativel com medidas preventivas contra os riscos de venenos ali previstos, pela anticientífica e enganosa expressão "defensivos agricolas", proporcionadora de publicidade ou propaganda comercial enganosa, abusiva e prejudicial, imposta por pressões notadamente de empresas e associações multinacionais mais preocupadas com os enormes lucros do que com a saúde da população e a melhoria da qualidade ambiental, além de violar os direitos dos consumidores com expressões e publicidade enganosasi e abusivas, é flagrantemente incompativel com as expressas normas do inciso II, in fine, do $\S 3^{\text {! }}$ e do $\S 4^{\circ}$ do art. 220 , da vigente Constituição Federal, não devendo prevalecer. Diante da flagrante incompatibilidade terminológica, indubitavelmente contrária às razões e aos objetivos das norrnas constitucionais em prol da saúde e do meio ambiente, impõem-se as medidas necessárias, junto ao Congresso Nacional, para os fins de substituição da inconciliável expressão "defensivos agricolas" por "agrotóxicos" na Ementa e nas normas dos arts. $1^{\circ}$ e $8^{\circ}$ da Lei n. 9.294, de 15-7-96, de forma harmônica com as normas do inciso ll do $\S 3^{\circ}$ e do $\S 4^{\circ}$ do art. 220 da vigente Magna Carta. 
dispensáveis à conscientização pública em defesa e preservação da qualidade ambiental propícia à saúde e a vida. Nesse sentido, justifica-se a ampliação desta parte introdutória, claramente desproporcional com a matéria dos capítulos integrantes do complexo e relevante tema, em razão da imperiosidade de esclarecer ou informar, insistentemente, para estimular ou despertar o interesse e a conscientização de todas as pessoas, físicas e jurídicas de direito público e de direito privado, não só sobre a importância e a progressiva atualidade do sério assunto de natureza interdependente e integrada, mas também sobre a necessidade de providências inadiáveis, em caráter prioritário, permanente e preventivo, favoráveis ao equilíbrio ecológico-ambiental propício à saúde pública e indispensável à continuidade da vida presente e futura.

\section{DIREITO COMO CONJUNTO DE PRINCÍPIOS E NORMAS DE CONDUTA SOCIAL}

Sem entrar nas divergências doutrinárias, em seu amplo sentido objetivo (norma agendl), é sempre oportuno recordar que se considera Direito um conjunto de princípios e normas de caráter obrigatório, com as respectivas sanções, impostos pelo Poder Público competente, no sentido de regular as ações, condutas ou relações das pessoas, individual, coletiva ou publicamente consideradas, na vida em sociedade, bem como manter a harmonia ou o equilibrio entre interesses diversos e a paz social. Como conjunto de princípios e normas obrigatórios de conduta social, mediante sanção, para a ordem e o equilibrio de interesses na própria sociedade, a finalidade fundamental do Direito "é servir a vida, regular a vida". Assim: "A ratio juris é uma força viva e móvel que anima os dispositivos e os acompanha no seu desenvolvimento"(16). Nesse sentido, o Direito, considerado como indispensável "conjunto de regras de conduta", tem um "preciso fim fundamental: aquele de assegurar a pacífica convivência" de ordem social. Tal "pacífica convivência somente será assegurada mediante a realização de dois objetivos essenciais: aquele da certeza do direito e aquele da certeza da observância do próprio direito"(17). O Direito objetivo ou norma agendi, classificado como público e privado, quer no âmbito nacional, quer nos âmbitos comparados, comunitário ou internacional, com força coercitiva em qualquer de suas manifestações, revela-se, incontestavelmente, um fenômeno de ordem social, um princípio ou uma norma antes de tudo de caráter geral e abstrato,

(16) Carlos Maximiliano, Hermenêutica e Aplicaçāo do Direito, $9^{a}$ ed., Rio de Janeiro, Forense, 1979, pp. 153, 154.

(17) Paolo Barile, Istituzione di diritto pubblico, $2^{\mathrm{a}}$ ed., Padova, CEDAM, 1975, p. 3: Clóvis Beviláqua, Teoria Geral do Direito Civil, $7^{\mathfrak{a}}$ ed., Rio de Janeiro, Francisco Alves, 1955, p. 11; Roberto de Ruggiero, Instituições de Direito Civil, v. I, $3^{\mathbf{a}}$ ed., trad. do orig. italiano por Ary dos Santos, São Paulo, Saraiva, 1971, pp. 15 e s. 
por imposição da sociedade, no interesse da própria sociedade. Onde há pessoas reunidas há obrigatoriamente tanto a sociedade como o Direito objetivamente considerado: Ubi societas, ibi ius. Por força desse princípio de ordem geral, não há Direito sem sociedade, nem há sociedade sem Direito. O Direito assume o caráter de força social propulsora, dinâmica, enérgica, coerentemente progressiva e ajustável às novas exigências sociais, quando visa a proporcionar, por via principal aos indivíduos e por via de conseqüência à sociedade, o meio favorável ao aperfeiçoamento e ao progresso da humanidade $^{(18)}$. Evidentemente, o Direito, consagrado pelas Nações democráticas de direito, como o Brasil (CF, art. $\left.1^{\circ}\right)$, é uma força social em sua origem, em sua natureza e em sua finalidade. Como princípio de adequação da pessoa humana à vida social, num dinâmico processo social de adaptação, a causa final do Direito é a consecução da Justiça ${ }^{(19)}$ ao restabelecimento do equilíbrio social, à realização do bem comum e à manutenção da paz social.

a) Noções de Direito Agrário, Direito Sanitário e Direito Ambiental como novos ramos do [lireito. Em síntese, sem entrar nas particularidades doutrinárias, de forma harmônica com os princípios e as normas do Direito em geral e do Direito Positivo em particular, em princípio, pela relevância e atualidade dos novos ramos jurídicos aplicáveis ao complexo tema em exposição, para convenientes esclarecimentos preliminares sobre seu conteúdo e seu progressivo alcance, tornam-se oportunas, ainda que brevemente, as seguintes noções:

Partindo do Direito Agrário, considera-se como tal o conjunto de princípios e normas gerais, especiais, complementares e excepcionais, de caráter obriggatório, impostos, coercitivamente, pelo Poder Público competente e reguladores das atividades agrícolas e similares inerentes à política agrícola, de forma compatível com a política da reforma agrária, mediante obrigatório planejamento do uso de imóveis, terras ou propriedades rurais e real execução dos planos correlatos com as limitações ou proibições vinculadas ao atendimento do princípio da função social cla propriedade pública e privada, observados os requisitos para aproveitamento e utilização racionais dos respectivos solos e demais recursos naturais, para recuperação dos recursos ou espaços degradados, para preservação do meio ambiente, dentre outros, vi-

(18) De Plácido e Silva, Vocabulário Juridico, cit., vols. I e II, pp. 75 e s.; Angelo Favata, Dizionario dei Termini Giuridici, $4^{\text {a }}$ ed., Piacenza, La Tribuna, 1974, p. 108; Henri Capitant, Vocabulário Juridico, ed. de 1975, cit., pp. 204, 205; Vicente Ráo, O Direito e a Vida dos Direitos, São Paulo, Resenha Universitária, 1976, vol. I, t. I, pp. 17, 18.

(19) Vicente Ráo, O Direito e a Vida dos Direitos, $2^{\mathrm{a}}$ ed., São Paulo, Resenha Universitária, 1976, vol. I, t. I, pp. 3, 18, 19; Caio Mário da Silva Pereira, Instituições de Direito Civil, Rio de Janeiro. Forense, 1986, vol. I, F. 5; Pontes de Miranda, Comentários à Constituição de 1967, com a Emenda n. 1, de 1969, São Pal lo, RT, 1973, t. 1, pp. 3 e s., 31 e s., 48 e s.; Rubens Limongi França, Manual de Direito Civil, 3ª ed., São Paulo, RT, 1975, vol. I, p. 9. 
sando à manutenção do equilíbrio ecológico-ambiental propício à sadia qualidade de vida e ao bem-estar da pessoa humana em todos os setores da sociedade rural, urbana e periférica. Já implícita e expressamente previsto nas normas constitucionais anteriores ${ }^{(20)}$, o Direito Agrário foi reafirmado, ampliado e consolidado pela vigente Magna Carta, que, além de ratificar a norma de competência da União, agora privativa, para legislar sobre 0 assunto (CF, art. 22, I), introduz, de forma inovatória, um Capítulo sobre a Política Agrícola de forma compatível com a Política Fundiária e da Reforma Agrária (CF, art. 187, c/c os arts. 184 a 186, 188 a 191).

Quanto ao Direito Sanitário, define-se como um conjunto de princípios e normas gerais, especiais, complementares e excepcionais, de caráter obrigatório, impostos, coercitivamente, pelo Poder Público competente e reguladores das ações e dos serviços públicos de saúde, individual, coletiva ou publicamente considerada, mediante obrigatório planejamento compreendido de medidas regulamentares, fiscalizatórias, controladoras e preventivas, por parte do Poder Público, bem como de planos de adequada execução diretamente da Administração Pública ou através de pessoas físicas ou jurídicas de direito privado, obedecido, além de outros requisitos, o atendimento integral, com prioridade para atividades preventivas, a execução de ações e serviços de vigilância sanitária, epidemiológica, de saneamento básico, de fiscalização e controle de alimentos e bebidas em geral, de substâncias e produtos psicoativos, tóxicos, radioativos, de proteção do meio ambiente saudável, dentre outros objetivos e atribuições essenciais à promoção, proteção, recuperação, melhoria e preservação da saúde pública e a conservação da vida. O Direito Sanitário, implícita e expressamente previsto nas normas constitucionais anteriores ${ }^{(21)}$, foi, em razão das progressivas exigências

(20) Observa-se que o Direito Agrário, implícito nas Constituições anteriores (Clmp./1824 e $1^{\text {CRep./ }}$ 1891), foi introduzido, com a expressão de "Direito Rural", pela CF/1934 como matéria de competência privativa da União para legislar sobre "normas fundamentais de direito rural" (art. $5^{9}, \mathrm{XIX}, c$ ). Com a omissão regressiva da CF/1937, o novo ramo do Direito, com a atual denominação de "Direito Agrário", foi introduzido pela EC n. 10/64, na vigência da CF/1946 (art. 5ª XV, a), reafirmado pelas Constituiçōes posteriores (CF/1967, art. $8^{\circ}, \mathrm{XVII}, b ; \mathrm{EC} / 1969$, art. $8^{\circ}, \mathrm{XVII}, b$ ), além de confirmado, ampliado e consolidado pela vigente Constituição (CF/1988, arts. 22, I, 187, c/c arts. 184 a 186, 188 a 191).

(21) Em nosso Direito Positivo, as primeiras normas fundamentais de Direito Sanitário foram previstas na Constituição do Império de 1824, com a garantia da inviolabilidade dos direitos civis e da saúde dos cidadãos (art. 179, XXIV). Na $1^{\text {a }}$ Constituição da República de 1891, as normas sobre saúde foram previstas implicitamente na declaração de direitos (art. 72). Tais normas, a partir da Constituição de 1934, implícitas no Capítulo dos direitos e garantias fundamentais (CF/1934, art. 113; CF/1937, art. 122), passaram a constituir matéria de competência legislativa, ora concorrente da União e dos Estados para "cuidar da saúde e assistência públicas" (CF/1934, art. 10, II), ora privativa da União para estabelecer "normas fundamentais da defesa e proteção da saúde, especialmente da saúde da criança" (CF/1937, art. 16, XXVII). Em progressiva evolução, a partir da Constituição de 1946, as normas sobre saúde, agora expressamente garantidas na "inviolabilidade dos direitos concernentes à vida" (CF/1946, art. 141; CF/1967, art. 150; EC/1969, art. 153; CF/1988, art. $\left.5^{\circ}\right)$, foram reafirmadas como matéria de competência privativa da União (CF/1946, art. $5^{\circ}, \mathrm{XV}, b$; 
notadamente socioeconômicas e sanitário-ambientais, reafirmado, ampliado e consolidado pela vigente Magna Carta. Evidentemente, a Constituição de 1988, além de garantir a inviolabilidade do direito à vida, incluída a inviolabilidade do direito à saúde (art. $5^{\circ}$ ) e de definir a competência concorrente da União, dos Esitados e do Distrito Federal (incluída a dos Municípios, implícita e expressamente, por se tratar de matéria de interesse local - CF, art. 24, XII, c/c o art. 30, I) para legislar sobre a proteção e defesa da saúde (art. 24, XII) e a competência comum de tais Unidades para cuidar da saúde e assistência pública (art. 23, II), introduziu, de forma inovatória, relevantes principios e normas reguladores de um conjunto de ações e serviços de iniciativa dos poderes públicos e da sociedade, destinados a assegurar os direitos relativos à saúde, à previdência e à assistência social (CF, art. 194), bem como a garantir a promoção, a proteção, a recuperação, a melhoria e a conservação da saúde, definida como direito de todos e dever do Estado (União, Estados, Distrito Federal e Municípios), além da prioridade para as atividades preventivas, em caráter permanente (CF, arts. 196 a 200), tudo visando a proteçer a vida presente e futura como inviolável direito fundamental da pessoa humana, individual, coletiva e publicamente considerada.

Tratando-se do Direito Ambiental, em harmônica noção, define-se como o conjunto de princípios e normas gerais, especiais, complementares e excepcionais impositos, coercitivamente, pelo Poder Público competente e disciplinadores de atividades transformadoras do meio ambiente, mediante obrigatório planejamento do uso racional dos recursos ambientais e adequada execução dos planos correlatos, com a proteção dos ecossistemas, as limitações ou proibições legais vinculadas ao atendimento do princípio da conciliação do desenvolvimento sócio-econômico com a preservação da qualidade ambiental e do equilíbrio ecológico-ambiental, tendo por objetivo a preservação, a recuperação, a melhoria e a conservação do meio ambiente e dos respectivos recursos ambientais (naturais, sócio-econômico-sanitários, culturais) e por finalidade a manutenção da sadia qualidade ambiental propícia à vida, à saúde pública, à segurança, à condição de total bem-estar e à paz social das presentes e futuras gerações. Em nosso Direito Positivo, o Direito Ambiental brasileiro, implícita e parcialmente previsto em algumas normas constitucionais anteriores ${ }^{(22)}$, foi, por força das progressivas exigên-

$\mathrm{CF} / 1967$, art. $8^{\circ}, \mathrm{XVII}, b ; \mathrm{EC} / 1969$, art. $\left.8^{\circ}, \mathrm{XVII}, b\right)$ e, na vigente Magna Carta, como abrangente matéria de competência concorrente (CF/1988, art. 24, XII) e competência comum (CF/1988, art. 23, II) das Unidades cla Federação, além da introdução dos novos principios e normas dos arts. 196 a 200, o que contribulu, decisivamente, para a consolidação das normas sanitárias legais vigentes, a expressa reafirmação e o fortalecimento do Direito Sanitário brasileiro. Dessa forma, fundamentado progressivamente nos principios e nas normas constitucionais, legais e regulamentares compativeis, o Direito Sanitário constitui novo ramo autônomo do Direito integrante do Sistema Jurídico nacional por imposição das contínuas e crescentes exigências notadamente socioeconômicas e sanitário-ambientais da época contemporânea.

(22) Omissas na Co stituição do Império (1824) e na 1a Constituição da República (1891), as primeiras normas constitucionais do Direito Ambiental brasileiro, implicita e parcialmente asseguradoras dos bens de valor cultural, foram previstas a partir da Magna Carta de 1934 (art. 10, III), 
cias socioeconômico e sanitário-ambientais, particularmente das três últimas décadas do século $X X$, consagrado, total e expressamente, por principios e normas legais anteriores e posteriores à Lei geral n. 6.938, de 31-0881, princípios e normas estes consolidados e ampliados pela vigente Constituição de 1988 (art. 225, c/c os arts. 23, III, IV, VI, VII; 24, VI, VII, VIII; 170, III, V, VI; 182; 186; 216; 220, §§ $\left.3^{\circ}, I I^{\circ} 4^{\circ}\right)$, com as adequações da respectiva legislação superveniente.

Evidentemente, tanto o Direito Agrário como o Direito Sanitário e o Direito Ambiental, autônomos nas interdisciplinares e multidisciplinares, todos caracterizados por normas de natureza repressiva e preventiva e vinculados aos princípios da Ciência e da Tecnologia, constituem novos e relevantes ramos do Direito Positivo integrante do Sistema Jurídico brasileiro, em progressiva evolução e adequado aperfeiçoamento ajustáveis às vertiginosas exigências particularmente socioeconômicas e sanitário-ambientais em todos setores da sociedade humana presente e futura.

Com estas breves noções, torna-se patente que, por força dos novos ramos do Direito (norma agendl) em apreciação, tanto o direito à saúde como o direito ao meio ambiente saudável constituem novos e relevantes direitos subjetivos, ou direitos públicos subjetivos, constitucionalmente assegurados a todas as pessoas, individual, coletiva ou publicamente consideradas, como direitos fundamentais relacionados com a incolumidade da vida (CF, arts. 5, 196, 225), com legitimação para agir em sua defesa e preservação, diante de lesão ou ameaça de lesão a seu direito, mediante ações judiciais próprias e previstas em nosso Direito Positivo, não de forma meramente facultativa (facultas agendl), mas sim de forma necessariamente obrigatória (obligatio agendl), por expressa determinação da norma agendi fundamental (CF, art. 5o, XXXV, LXXIII, 225).

b) Princípios e normas constitucionais aplicáveis. Dentre os princípios e as normas constitucionais, direta e indiretamente relacionados com as questões da Política Agrícola e agrotóxicos, da Política Sanitária e da Política Ambiental, destacam-se os seguintes:

Tratando da organização nacional, a Constituição estabelece que a organização político-administrativa compreende a União, os Estados, o Dis-

reafirmadas e ampliadas pelas Constituições de 1937 (art. 134), de 1946 (art. 175), com os acréscimos da de 1967 (art. 172 e parágrafo único, no tocante às jazidas arqueológicas) e da EC n. 1 , de 1969 (art. 180, parágrafo único). Embora timidamente, a EC n. 1, de 1969 introduziu, de forma expressa, no Título da Ordem Econômica e Social, a primeira norma sobre Ecologia, no setor agrícola (art. 172). A Constituição de 1988, ajustando as suas normas às notórias exigências socioeconômicas e sanitário-ambientais, introduz relevantes princípios e normas sobre a proteção do meio ambiente saudável, com todos os seus componentes, no interesse das presentes e futuras gerações (art. 225, c/c arts. 24, VI, 23, VI, VII, 170, III, V, VI, dentre outros), consolidando as normas legais e regulamentares tanto anteriores, então, vigentes como as supervenientes compativeis. Assim, o Direito Ambiental, hoje, de forma autônoma mas interdependente, constitui relevante ramo do Direito integrante do Sistema Jurídico brasileiro. 
trito Federal e os Municípios, todos autônomos (art. 18) para legislar e tratar de assuntos de interesse dos respectivos territórios, nos termos constitucionais. Em vinculação à autonomia de tais Unidades Federadas para autogovernar-se ou reger-se, de forma independente mas harmônica entre si, sempre com a observância dos princípios e das normas gerais característicos do regime federativo, a própria Magna Carta define as respectivas competências, tratando-se de assunto de fundamental relevância e complexidade, de obrigatória reflexão perante todo tema, como o presente, que envolve matéria de interesse público. Em resumo, dentre as atribuições das Unidades da Federação, direta e indiretamente relacionadas com a proteção do meio ambiente e vinculadas às questões notadamente sócio-econômico-sanitárias e agrícolas com os respectivos agrotóxicos, no âmbito das competências constitucionalmente definidas, evidenciam-se as seguintes:

- Competência soberana ou exclusiva (interna e externa) da União. Interessando ao presente tema apenas a competência da União no âmbito interno, evidenciam-se, dentre os princípios, diretrizes e normas gerais de competência exclusiva da União e de observância obrigatória pelas Unidades da Federação, no exercício das respectivas atribuições: elaborar e executar planos nacionais e regionais de ordenação do território e de desenvolvimento econômico e social; planejar e promover a defesa permanente contra calamidades públicas, especialmente as secas e as inundações; instituir sistema nacional de gerenciamento cle recursos hídricos e definir critérios de outorga de direitos de seu uso; instituir diretrizes para o desenvolvimento urbano, inclusive habitação, saneamento básico e transportes urbanos; explorar os serviços e instalações nucleares de qualquer natureza e exercer monopólio estatal sobre o assunto, atendidos os princípios e condições constitucionais, como, dentre outros, autorizar a utilização de radioisótopos para a pesquisa e usos medicinais, agrícolas, industriais e atividades análogas (CF, art. 21, IX, XVIII, XIX, XX, XXIII).

- Competência privativa da União, dos Estados, do Distrito Federal e dos Municípios. Trata-se de competência para legislar sobre matérias de interesse direto e imediato no âmbito do território de cada Unidade da Federação. Partindo do território nacional, por força da norma constitucional, compete privativamente à União legislar sobre, dentre outras matérias: direito civil (propriedade imóvel, com seu solo e respectivos acessórios naturais e artificiais); direito agrário, águas; recursos minerais; geologia; atividades nucleares de qualquer natureza; normas gerais de licitação e contratação em todas as modalidades; propaganda comercial (CF, art. 22, I, IV, XII, XVIII, XXVI, XXVII, XXIX). A competência privativa dos Estados para legislar sobre assunto de imediato interesse estadual se encontra assegurada nas normas do art. 25 da Constituição Federal. Além da competência para sua auto-organiza- 
ção, são reservadas aos Estados as competências que não Ihes sejam vedadas pela Constituição. Os Estados podem, mediante lei complementar, instituir regiões metropolitanas, aglomerações urbanas e microrregiões, constituídas por agrupamentos de municípios limítrofes, para integrar a organização, o planejamento e a execução de funções públicas de interesse comum (CF, art. $25, \S \S 1^{\circ}$ e $3^{\circ}$ ). Incluem-se nesta competência as matérias relacionadas com a política agrícola, a política sanitária (em tudo que se refere à saúde) e a política ambiental de interesse imediato às peculiaridades estaduais. A competência privativa do Distrito Federal para legislar sobre assunto de imediato interesse distrital, relacionada notadamente com a matéria sanitária e ambiental, encontra-se definida nas normas constitucionais do art. 32 e $\S 1^{\circ}, \mathrm{c} / \mathrm{c} \circ$ art. 18. A competência privativa dos Municípios para legislar sobre matérias de imediato interesse local, diretamente relacionadas com as questões ambientais, urbanísticas, sanitárias, de saneamento básico, dentre outras, encontra-se assegurada nas normas dos arts. 29, 30, I, V, VII, VIII, 182, c/c o art. 18, da vigente Magna Carta.

- Competência comum da União, dos Estados, do Distrito Federal e dos Municípios. Trata-se de competência sobre assunto de interesse comum das Unidades de Federação, em igualdade de condições, de forma compatível com o princípio da independência e harmonia dos Poderes Públicos entre si, em cooperação recíproca e sintonia, sem superposições e paralelismos, sem interferências nas respectivas competências constitucionais, no legítimo interesse de todos. Como atribuições de natureza executiva, sem prejuízo da competência legislativa privativa, concorrente ou suplementar de cada Unidade Federada sobre assunto de interesse do respectivo território, evidenciam-se, dentre outras funções de competência comum diretamente relacionadas com a proteção do patrimônio ambiental e da saúde pública, as seguintes: conservar o patrimônio público (nos âmbitos nacional, estadual, distrital e municipal); cuidar da saúde e da assistência pública (a proteção da sadia qualidade de vida interessa à saúde de todos); proporcionar os meios de acesso à cultura, à educação e à ciência; proteger o meio ambiente e combater a poluição em qualquer de suas formas; preservar as florestas, a fauna e a flora; fomentar a produção agropecuária e organizar o estabelecimento alimentar; promover programas de construção de moradia e a melhoria das condições habitacionais e de saneamento básico (CF, art. 23, I, II, V, VI, VII, VIII, IX, c/c os arts. 30, VII; 170, III, V, VI; 196 a 200; 216; 218; 225).

- Competência concorrente da União, dos Estados (incluindo implicitamente a dos Municípios integrantes dos Estados e dos Territórios em matérias específicas de interesse local) e do Distrito Federal. Trata-se de competência para legislar concorrentemente sobre, dentre 
outras matérias, direito tributário, econômico, urbanístico, proteção do meio ambiente e defesa da saúde, de acordo com as respectivas peculiaridades, observadas as normas gerais de competência da União ou dos Estados (na falta daquelas da União e compatíveis com as da lei federal superveniente) (CF, art. 24, II, VI, VII, VIII, XII, § 3ㅇ, c/c os arts. $18,23,29,30,145,156,170$, III, V, VI, 182, 196 a 200, 216, 225).

- Competència suplementar das Unidades da Federação. Trata-se de competência de Unidades Federadas para legislar sobre questões específicas não previstas nas normas gerais, dentre outras, ambientais, alimentares, sanitárias, para o preenchimento dos vazios das normas existentes, de forma acessória e compatível com as respectivas peculiaridades, observadas as normas gerais de competência privativa ou concorrente da União ou do Estado, de acordo com as circunstâncias de cada caso (CF: competência suplementar dos Estados: arts. 22,

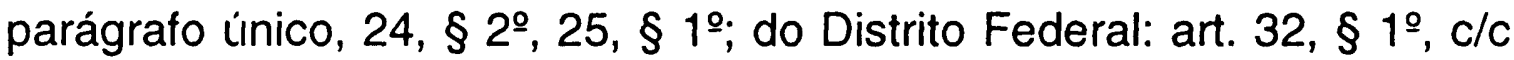
os arts. 22, parágrafo único, 30, II; dos Municípios: art. 30, II).

- Princípios da conciliação do desenvolvimento sócio-econômico e agrícola-urbanístico-construtivo com a preservação da sadia qualidade ambiental propícia à saúde pública e à vida. Trata-se de expressos princípios gerais da atividade econômica, vinculados ao princípio da prevenção de danos ambientais, a serem obrigatoriamente atendidos de forma conciliatória com os princípios constitucionais, dentre outros, da função social da propriedade (pública e privada), da defesa do consumidor (incluída a defesa da saúde pública), da defesa do meio ambiente (incluída a defesa da sadia qualidade de vida) com todos os seus valores naturais, sócio-econômico-sanitários, culturais, em todas as zonas, tanto urbana e de expansão urbana como rural (CF, arts. 170, III, V, VI, 174, 180, 182, 184 e 190, 196 a $\left.200,220, \S \S 3^{\circ}, 11,4^{\circ}, 225\right)$.

c) Normas legais e regulamentares sobre Direito Agrário com as respectivas diretrizes e normas sobre alimento e agrotóxicos, Direito Sanitário e Direito Ambiental. Invertendo a ordem e partindo do Direito Ambiental, no tocante à legislação do período anterior e posterior à Lei geral n. 6.938, de 31-8-81, sobre a Política Nacional do Meio Ambiente, com as respectivas adequações, alterações e complementações decorrentes da Constituição de 1988 , reporta-se aos nossos trabalhos sobre o assunto já publicados ${ }^{(23)}$.

Legislação integrante do Direito Agrário. Dentre os textos tradicionais da nova legislação imposta pelas progressivas exigências notadamente

(23) Legislação Ambiental no Brasil, in Revista de Direito Civil, Imobiliário, Agrário e Empresarial, São Paulo, RT, 1993, v. 76/56; Agrotóxicos no Sistema Legal Brasileiro, in Revista de Direito Ambiental, São Paulo, RT, 1997, v. 8/139. 
socioeconômicas, agrícola-urbanísticas e sanitário-ambientais ajustáveis à vigente Constituição sobre a Política Agrária, os agrotóxicos e respectivas restrições legais, de forma harmônica com a política de proteção do meio ambiente saudável, de proteção dos alimentos e dos consumidores, de proteção da saúde pública e da vida, destacam-se, observada a ordem cronológica, com as alterações e os acréscimos dos textos correlatos, os seguintes: Decreto n. 24.114, de 12-4-34, sobre aprovação do Regulamento de Defesa Sanitária Vegetal; Lei n. 4.054, de 30-11-64, sobre o Estatuto da Terra (com as alterações e os acréscimos notadamente das Leis n. 6.746, de 10-12-79, n. 7.647, de 19-1-88, do Dec.lei n. 2.431, de 12-5-88, da Medida Provisória n. 2.183-56, de 24-8-2001, antes MP n. 2.027-42/2000, convalidando os atos praticados com base na MP n. 2.109-48/2001); Lei $n$. 4.947, de 6-4-66, sobre normas de Direito Agrário (Dec. regulamentar $n$. 59.428, de 27-10-66, com as alterações do Dec. n. 433, de 24-1-92); Dec.lei n. 986, de 21-10-69, que fixa normas básicas sobre alimentos (com as alterações, dentre outras, da Medida Provisória n. 2.190-34, de 23-8-2001, que revoga o art. $\left.4^{\circ}\right)$; Lei n. 5.889, de 8-6-73, sobre normas reguladores do trabalho rural (com os acréscimos da Lei n. 9.300, de 29-8-96); Lei n. 5.969, de 11-12-73, sobre o Programa de Garantia da Atividade Agropecuária PROAGRO (com as alterações das Leis n. 6.685, de 3-9-79, n. 7.890, de 23-11-89 - Dec. regulamentar n. 175, de 10-7-91); Lei n. 6.225, de 14-775 , sobre planos de proteção do solo e de combate à erosão; Lei n. 6.662, de 25-6-79, sobre Política Nacional de Irrigação (com as alterações da Lei n. 8.657, de 21-5-93); Lei n. 6.751, de 10-12-79, sobre melhoria da habitação de trabalhadores rurais; Lei n. 6.894, de 16-12-80, sobre inspeção e fiscalização de fertilizantes e outros destinados à agricultura (com as alterações da Lei n. 6.934, de 13-7-81); Lei n. 7.802, de 11-7-89, sobre agrotóxicos e afins: pesquisa, experimentação, produção, embalagem, rotulagem, transporte, armazenamento (com as alterações das Leis n. 9.294, de 15-796, n. 9.974, de 6-6-2000, n. 10.167, de 27-12-2000); Lei n. 7.889, de 2311-89, sobre inspeção sanitária e industrial de produtos de origem animal; Lei n. 8.171, de 17-1-91, sobre Política Agrícola (com as alterações e os acréscimos das Leis n. 8.174, de 30-1-91, n. 9.272, de 3-5-96, n. 9.712, de 20-11-98); Lei n. 8.661, de 2-6-93, sobre incentivos fiscais para a capacitação tecnológica da indústria e da agropecuária; Lei n. 8.874, de 29-4-94, sobre empreendimentos industriais e agrícolas em áreas da SUDAM e SUDENE; Lei n. 9.649, de 27-5-98, sobre a organização da Presidência da República e dos Ministérios, com a atual denominação do MINISTÉRIO DA AGRICULTURA E DO ABASTECIMENTO, a definição das áreas de competência, arts. 13, III, 14, III, "a" a " $n$ ", 17, VI (com as alterações da Medida Provisória n. 2.216-37, de 31-8-2001, antecedida de outras MPs com atos reiteradamente convalidados, como, dentre outros, a criação do MINISTÉRIO DO DESENVOLVIMENTO AGRÁRIO, de competência harmônica e 
integrada, de forma especial, com os MINISTÉRIOS da AGRICULTURA E DO ABASTECIMENTO, do DESENVOLVIMENTO, INDÚSTRIA E COMÉRCIO EXTERIOR, da EDUCAÇÃO, da INTEGRAÇÃO NACIONAL, do MEIO AMBIENTE, da SAUÚDE, do PLANEJAMENTO, ORÇAMENTO E GESTÃO, da CIÉNCIA e daı TECNOLOGIA). Além das sucessivas alterações legais e dos respectivos regulamentos, observa-se grande e progressivo número de atos normativos (Decretos, Portarias, Resoluções, Circulares) relacionados com a legislação integrante do Direito Agrário nacional.

Legislação integrante do Direito Sanitário. Dentre os textos tradicionais em vigor e da nova legislação imposta pelas crescentes exigências, particularmente socioeconômicas e sanitário-ambientais ajustáveis à vigente Constituição sobre a Política Sanitária, de forma compatível com a Política Agrária e a Política Ambiental vinculadas à proteção da saúde pública e à conservação da vida, tornam-se patentes os seguintes: Lei n. 5.318, de 299-67, sobre a insitituição da Política Nacional de Saneamento em harmonia com a Política Nacional de Saúde e a criação do Conselho Nacional de Saneamento - CONSANE; Dec.-lei n. 986, de 21-10-69, que fixa normas básicas sobre alimentos (Dec. regulamentar $n$. 72.718, de 29-8-73, que institui normas gerais sobre irradiação de alimentos); Lei n. 6.360, de 23-9-76, sobre vigilância sanitária a medicamenos, drogas, insumos, cosméticos, saneantes e outros produtos (com as alterações da Lei n. 9.782, de 26-1-99, que define o Sistema. Nacional de Vigilância Sanitária e cria a Agência Nacional de Vigilância Sanitária, da Lei n. 9.787, de 10-2-99, sobre medicamento genérico, da Medida Provisória n. 2.190-34, de 23-8-2001); Lei n. 6.437, de 208-77, sobre infrações à legislação sanitária federal com as alterações da Lei n. 7.967, de 22-12-89, sobre o valor das multas por infração à legislação sanitária, da Merdida Provisória n. 2.190-34, de 23-8-2001); Lei n. 7.488, de 11-6-86, sobre a instituição do "Dia Nacional de Combate ao Fumo", em 29 de agosto de cada ano, com o objetivo de alertar a população contra os malefícios do uso do fumo; Lei n. 8.080, de 19-9-90, sobre as condições para a promoção, proteção e recuperação da saúde, como direito fundamental do ser humano (com as alterações da Lei n. 8.142, de 28-12-90, sobre o SUS e Fundo Nacional de Saúde - FNS; Dec. n. 806, de 24-4-93, EC n. 12/ 96, que acrescenta o art. 74 ao ADCT sobre recursos ao FNS); Lei n. 8.543, de 23-12-92, sobre a obrigatória advertência em rótulos e embalagens de alimentos industrializados para evitar a doença celíaca; Lei n. 8.918, de 147-94, sobre padronização, classificação, registro, inspeção, produção e fiscalização de bebidas; Lei n. 8.974 , de 5-1-95, sobre normas e técnicas de engenharia genética e liberação do meio ambiente de organismos geneticamente modificados (OGM), com expressas atribuições aos órgãos de fiscalização dos Ministérios da Saúde, da Agricultura e do Abastecimento, do Meio Ambiente (com as alterações e denominações ministeriais da Lei n. 9.649, 
de 27-5-98, da Medida Provisória n. 2.216-37, de 31-8-2001); Lei n. 9.005, de 13-3-95, sobre obrigatoriedade da iodação do sal destinado ao consumo humano; Lei n. 9.055, de 1-6-95, sobre a extração, industrialização, utilização, comercialização e transporte do asbesto/amianto e de outros comprovadamente nocivos à saúde humana; Lei n. 9.273, de 3-5-96, sobre a obrigação da inclusão de dispositivo de segurança que impeça a reutilização de seringas descartáveis; Lei $n$. 9.294, de 15-7-96, sobre restrições legais ao uso e à propaganda de produtos fumígeros, bebidas alcoólicas, medicamentos, produtos, práticas ou serviços que possam ser nocivos à saúde e ao meio ambiente (com as alterações da Lei n. 10.167, de 27-12-2000); Lei $n$. 9.431, de 6-1-97, sobre a obrigatoriedade da manutenção do programa de controle de infecções hospitalares pelos hospitais do País; Lei n. 9.434, de 4-2-97, sobre a remoção de órgãos, tecidos e partes do corpo humano para fins de transplante e tratamento (com as alterações da Lei n. 10.211, de 233-2001); Lei n. 9.605, de 12-2-98, sobre a definição de crimes de poluição em níveis que resultem ou possam resultar danos à saúde humana, ou provoquem a mortalidade de animais, ou a destruição significativa da flora (com os acréscimos da Medida Provisória n. 2.163-41, de 24-8-2001); Lei n. 9.649, de 27-5-98, sobre a organização da Presidência da República e dos Ministérios, observada a relevância da competência do MINISTÉRIO DA SAÚDE na área da saúde ambiental ou saúde pública e das ações de promoção, proteção e recuperação da saúde individual e coletiva, incluída a saúde dos trabaIhadores e dos indios (com as alterações da Medida Provisória n. 2.216-37, de 31-8-2001); Lei n. 9.656, de 3-6-98, sobre planos e seguros privados de assistência à saúde (com os acréscimos da Lei n. 9.961, de 28-1-2000, que cria a Agência Nacional de Saúde Suplementar - ANS, com as alterações da Lei n. 10.185, de 12-2-2001); Lei n. 9.677, de 2-7-98, sobre alterações de dispositivos do Código Penal, referentes aos delitos considerados hediondos crimes contra a saúde pública, no tocante à degradação, adulteração ou falsificação de substâncias alimentícias ou medicinais; Lei n. 9.965, de 27-42000 , sobre restrição da venda de esteróides ou peptídeos anabolizantes para uso humano; Lei n. 10.191, de 14-2-2001, sobre a aquisição de produtos a implementação de ações de saúde no âmbito do Ministério da Saúde; Lei n. 10.205, de 21-3-2001, sobre coleta, processamento, estocagem, distribuição e aplicação de sangue, seus componentes e derivados; Lei n. 10.216, de 6-4-2001, sobre a proteção e os direitos das pessoas portadoras de transtornos mentais. É oportuno evidenciar, como relevante texto legal direta e indiretamente relacionado com o Direito Sanitário, a Lei n. 7.078, de 11-9-90, sobre o Código de Proteção e Defesa do Consumidor, tendo por objetivos, dentre outros: o respeito à saúde e à segurança dos consumidores, à melhoria de sua qualidade de vida (art. $4^{\circ}$ ). Observa-se, ainda, a existência de grande e crescente número de atos normativos (Decretos, Portarias, Resoluções) relacionados com a legislação integrante do Direito Sanitário brasileiro. 


\section{DIREITO À SAÚDE E PROBLEMÁTICA DOS AGROTÓXICOS NO BRASIL}

Em breves advertências críticas, não obstante a consagração constitucional da Política Sanitária, de forma harmônica com a Política Agrícola, com a Política Econômica, a Política Educacional, a Política Ambiental, a Política científico-tecnológica e a existência de grande número de normas jurídicas protecionais do patrimônio sanitário humano, adverte-se que, na prática, pela notoriedade dos fatos, patente é a inaplicação ou a aplicação inadequada e flagrante e a violação de tais normas, em face do inquietante agravamento da degradação vertiginosa dos recursos ambientais e das conseqüências danosas contra a saúde ambiental ou a saúde pública, em decorrência da ampliação progressiva de fontes poluentes, tanto no âmbito nacional, em todas as regiões do País, como nas esferas estaduais, distritais e municipais, com prejudiciais efeitos diretos e indiretos contra a vida, a saúde pública, o bem-estar e a paz social. No Brasil, especificamente se tratando de substâncias químicas, físicas ou biológicas de ação contra o meio ambiente e a saúde pública, tanto os agrotóxicos como seus afins e componentes já se tornaram notórias fontes de poluição ambiental, demonstrando-se que nosiso país, lamentavelmente, vem se distinguindo, de forma especial, pelo uso inadequado de agrotóxicos "como o terceiro maior consumidor do mundo"(24). Nesse sentido, adverte a doutrina científica que "os países subdesenvolvidos, entre os quais o Brasil, absorvem $20 \%$ dos agrotóxicos produzidos no mundo", salientando que esses países, "ao mesmo tempo, são responsáveis por $75 \%$ das intoxicações com agrotóxicos". O resultado da aplicação indiscriminada e excessiva de produtos contaminantes e altamente tóxicos já é a elevadíssima taxa de veneno no sangue da população brasileira, com preocupante perigo imediato e mediato contra a saúde pública(25). Tal realidade gritante, além de ocasionar "85 por cento das doenças degenerativas:", como o "câncer"(26), revela, notadamente em muitos locais e regiões do País, uma preocupante situação de "crime de genocídio, silencioso e progressivo, no espaço e no tempo, cujos autores deviam ser julgados por um novo Tribunal de Nuremberg"(27). No tocante à elevadíssima taxa de veneno rio sangue da população por agrotóxicos em nosso país, adverte o cientista Antenor Ferrari que, enquanto "os ingleses têm 14,4 ppb (partes por bilhão) de veneno no sangue, os americanos $22,7 \mathrm{ppb}$, os argen-

(24) "A terra envenenaida - Economia/Agricultura: os efeitos de uso de agrotóxicos", in Revista Retrato do Brasil, 34/54. Nesse sentido, Márcio Bontempo, Relatório ORION - Denúncia médica sobre os perigos dos alimento:s industrializados e agrotóxicos, $3^{\text {a }}$ ed., Porto Alegre, L\&PM, 1986, pp. 122 e s. (25) Antenor Ferrari, AGROTÓXICOS - a praga da dominação, cit., pp. 43, 44. Nesse sentido: Elza Flores Rüegg e outros, Impacto dos Agrotóxicos sobre o ambiente, a saúde e a sociedade, São Paulo, Ícone, 1986, p. 10; Márcio Bontempo, Relatório ORION - Denúncia médica, cit., pp. 124 e s. (26) Márcio Bontempo, ob. cit., pp. 14, 124, 134.

(27) Farid Chahad (Juiz de Direit - Presidente do II Tribunal do Júri de São Paulo), Prefácio do Relatório ORION citado do Médico Márcio Bontempo, p. 10. 
tinos 43,3 ppb", os brasileiros têm a impressionante taxa de "572,6 ppb"(28). Lamentavelmente, tais denúncias gravíssimas da idônea comunidade científica do Brasil vêm sendo, de forma inquietante, reafirmadas pelos próprios relatórios oficiais ${ }^{(29)}$ e pela jurisprudência dos Tribunais ${ }^{(30)}$.

Além do mais, considerando a grave realidade da importação pelo Brasil de produtos agrotóxicos de uso proibido nos países exportadores ${ }^{(31)}$, juridicamente inadmissivel, data venia, foi o veto do Presidente da República ao art.

(28) Antenor Ferrari, ob. cit., p. 44, nota de rodapé 2.

(29) Governo do Brasil, O Desafio do Desenvolvimento Sustentável - Relatório do Brasil perante a CONFERÉNCIA DO RIO/92, cit., pp. 129 e s., demonstrando o quadro dos principais impactos ambientais, decorrentes, dentre outras atividades perigosas, da pulverização de agrotóxicos com o uso de aviāo ou de outros instrumentos, da aplicação maciça, do alto consumo, do uso de grandes quantidades de agrotóxicos em todas as Regiōes do Pais; UNICAMP - Área de Saúde Ambiental e Toxicologia, Informaçōes Médicas de Urgência nas intoxicações por produtos agrotóxicos, Ministério da Saúde, Secretaria de Vigilância Sanitária e Divisão de Meio Ambiente e Ecologia Humana, Relatório: Programa de Treinamento, São Paulo, UNICAMP, 1996; Comissão de Cidadania e Direitos Humanos - ASSEMBLÉIA LEGISLATIVA-RS, Relatório AZUL 1995, com sérias advertências sobre "Suicidio e uso de agrotóxicos em Venâncio Aires e outros locais", Diretoria de ANAIS/RS, pp. 243 e s.; Revista GLOBO CIÊNCIA, "Uma epidemia de suicidios" - "Ecologistas culpam os agrotóxicos da lavoura do fumo", Rev. GC, a. 6, n. 64, pp. 28 a 31, ed. nov./96. Tão grave é a realidade no Brasil sobre o uso de produtos tóxicos perigosos que motivou a oportuna "CAMPANHA DA FRATERNIDADE 2001: VIDA SIM, drogas não!"

(30) Dentre as decisões notáveis e aplicáveis ao presente tema, destacam-se: 1) CRIME CONTRA A SAÚDE PÚBLICA: Ação Penal - Substância nociva à saúde - Agrotóxico - Envio pelo correio de amostras em embalagens vulneráveis a coletividade desfamiliarizada com os riscos do produto. Ação procedente. Condenação mantida, CP, art. 278 - Ap. 472.211-5 - $8^{\text {a }} \mathrm{C}$. - TACrSP - j. 11-2-88, Rel. Juiz Manoel Carlos, in RT 629/336. 2) QUEIMA DA PALHA DA CANA-DE-AÇÚCAR: Ação Civil Pública - Risco à saúde de toda a população e à incolumidade animal, com a morte de espécies em processo de extinção, além da degradação ambiental. Prevalência da proibição prevista na Lei n. 4.771/65 e na Lei n. 6.938/81, com o reconhecimento da inconstitucionalidade do Decreto estadual n. 42.056/97 - ApCiv. 99.551-5/1 - 6a C. - TJSP - j. 30-8-99, Rel. Des. Telles Corrêa, in Rev. de Direito Ambiental v. 18/358 (com a evidência da gravissima poluição de iminente dano à saúde e ao meio ambiente pelo agravante fato da queima da palha com a mais alta concentração de agrotóxicos notadamente decorrentes da excessiva pulverização aérea). 3) MEIO AMBIENTE. SAÚDE: Mandado de Segurança - Cultivo de organismo geneticamente modificado - OGM. Soja transgênica. Falta de expressa autorização do Poder Público Federal (Ministérios da Saúde, do Meio Ambiente e da Agricultura) e da licença ambiental da autoridade competente - Lei n. 8.974/95 c/c Lei n. 6.938/ 81. llegalidade que põe em risco a saúde e o meio ambiente. Interdição da atividade. Concedida a Segurança, deu-se provimento ao Recurso do Estado, com a interdição da atividade ilegal - MS

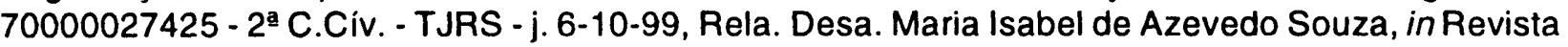
de Direito Ambiental v. 18/347. 4) ORGANISMOS GENETICAMENTE MODIFICADOS: Ação Civil Pública - Liberação de espécies. Obrigatoriedade da realização do prévio ElA. Inconstitucionalidade do inc. XIV do art. $2^{9}$ do Dec. 1.752/95 e das Insts. Normativas 3 e 10 da CTNBio que dispensam o EIA/RIMA nestes casos. Necessidade de normas sobre a segurança alimentar, de acordo com a Constituição, o Código de Defesa do Consumidor e a legislação ambiental - Proc. 1998 34.00.027682-0 - 6 Vara - Seção Judiciária do DF - j. 26-6-2000 - Juiz Federal Antônio Souza Prudente. Trata-se de importante decisão que julgou procedente a ação para condenar a União Federal a exigir a realização de prévio Estudo de Impacto Ambiental da Monsanto do Brasil Ltda., solidamente fundamentada com a adoção de pareceres técnico-jurídicos de respeitados Autores, como, dentre outros, do Prof. Paulo Affonso Leme Machado (sobre o "Princípio da precaução e o direito ambiental") e por força das expressas normas constitucionais e legais vigentes, in Rev. de Direito Ambiental v. 20/309.

(31) Antenor Ferrari, ob. cit., p. 29. 
57 do Projeto de I_ei n. 1.164, de 1991, hoje, Lei n. 9.605, de 12-2-98, sobre sanções penais $€$ administrativas de natureza ambiental, que definia como crime ambiental: "importar ou comercializar substâncias ou produtos tóxicos ou potencialmente perigosos ao meio ambiente e à saúde pública, cuja comercialização seja proibida em seu país de origem". As razões do veto ao art. 57 em análise, de forma imprudentemente contraditória, com toda a vênia, além de propiorcionarem a continuidade da temerária condescendência para com a grave: realidade, no Brasil, da importação e comercialização de produtos agrotóxicos altamente perigosos contra a qualidade de vida, a saúde, de uso proibiclo no país de origem, já com notórios e incalculáveis danos ambientais e à seiúde da população rural, urbana e periférica, são flagrantemente incompatíveis tanto com as normas constitucionais e legais nacionais (CF, art. 225, § 1, V, c/c os arts. 23, II, VI, VIII; 24, VI, XII; 170, V, VI; 186; 200, I, II, VII; 220, §§ 3으, II, 4ㅇ; Lei n. 6.938, de 31-8-81, art. 3ㅇ, III, a; Lei n. 7.802, de 11-7-89) como com as normas internacionais aprovadas pelo Brasil (notadamente AGENDA 21, Caps. 19-F, 20, 21, 22), impondo-se as inadiáveis medidas da comunidade científico-jurídica, perante o Congresso $\mathrm{Na}$ cional, para o resitabelecimento da oportuna norma do 57 do Projeto de Lei n. 1.164/91, hoje Lei n. 9.605, de 12-2-98, de forma compativel com as vigentes normas constitucionais e legais, nacionais e internacionais, no legítimo interesse da defesa e preservação da sadia qualidade ambiental propícia à vida em prol do bem-estar da sociedade presente e futura.

\section{DEVERES E RESPONSABILIDADES DO PODER PÚBLICO E DA COLETIVIDADE PARA CUMPRIR, ADEQUAR, ATUALIZAR E APLICAR AS NORMAS SOBRE AGROTÓXICOS INTEGRANTES DO SISTEMA JURÍDICO BRASILEIRO}

Conforme já se demonstrou nesta palestra, por força dos principios e das normas consititucionais e legais vigentes, expressas são a autonomia e as competências de todas as Unidades da Federação, de forma harmônica e integrada, para legislar sobre matérias de interesse dos respectivos territórios, executar ou cumprir, adequar, atualizar e aplicar as normas correlatas de forma ajustável às exigências sociais concretas ao bem-estar de todos. Conseqüentemente, expressos são os deveres e as responsabilidades impostos à Administração Pública direta e indireta de qualquer dos Poderes da Uniäo, dos Estados, do Distrito Federal e dos Municípios, ou de qualquer pesisoa física ou jurídica de direito privado prestadora ou realizadora de açõe:s e serviços públicos de saúde, para o desempenho, de forma permanente, preventiva e eficaz, de suas atribuições, sempre sujeita à obrigatória obediência aos princípios da legalidade, impessoalidade, moralidade, publicidade, probidade, eficiência, dentre outros, no interesse 
público (CF, art. 37). Em matérias de agricultura, saúde e meio ambiente, asseguradas pelos princípios e normas constitucionais e legais, integrantes, respectivamente, do Direito Agrário, do Direito Sanitário e do Direito Ambiental, tais deveres e responsabilidades, além de inerentes aos Poderes Públicos, estendem-se à coletividade (pessoas físicas ou jurídicas de direito privado, com ou sem fins lucrativos) por determinação constitucional (CF, arts. 196, 197, $200 \mathrm{c} / \mathrm{c}$ o art. 225).

Trata-se de princípios e normas fundamentais, de caráter obrigatório, impondo deveres inerentes à "contínua vigilância do todos"(32), particularmente da comunidade jurídica do País, que tem o dever de defender a Constituição, de lutar pela boa aplicação das leis, pela rápida administração da Justiça, pela permanente promoção da educação ambiental, educação sanitária, educação científico-tecnológica, pelo aperfeiçoamento da cultura e das instituições jurídicas do País (CF: Poder Judiciário, arts. 92 a 126; funções essenciais à Justiça, arts. 127 a 135; princípios da educação ambiental, da conciliação de interesses e da prevenção de danos ambientais, arts. 170, III, V, VI, 186, 187, 196 a 200, 216, 218, 225, § 1ㅇ, I a VIII, §§ 2a 6웅 Lei $n$. 8.906, de 4-7-94, art. 44, I), visando à promoção do bem de todos (CF, art. $3^{\circ}$, IV). Os básicos princípios e normas constitucionais devem tornar-se, cada vez mais, "efetivos e eficientes", uma vez que a Constituição, sendo "a égide da paz, a garantia da ordem", tem "em mira os fins", fornence "meios para os atingir", devendo os responsáveis "descobri-los e aplicá-los" ao bem de todos $^{(33)}$. Assim: "É necessário compreendê-la corretamente, saber o que é a Constituição e como ela deve ser elaborada e aplicada para que possa atingir suas finalidades"(34).

Com essas breves mas claras demonstrações, evidencia-se que o descumprimento das vigentes imposições constitucionais e legais correspondentes, com as conseqüentes contaminações agrícolas e alimentares, as lesões ao meio ambiente, à saúde e à vida, sujeitará a autoridade públi$\mathrm{ca}$, o servidor ou qualquer agente competente, ou qualquer pessoa física ou jurídica de direito privado infratora, às responsabilidades e respectivas sanções éticas ou disciplinares, políticas, administrativas, civis, penais ou criminais aplicáveis de acordo com as circunstâncias do caso concreto (CF,

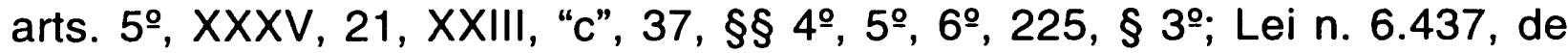
20-8-77, arts. 4ㅇ, 10; Lei n. 6.938, de 31-8-81, arts. 14 e $\S \S 1^{\circ}$ a $4^{\circ}, 15$ e $\S \S$ $1^{\circ}$ e 2o; Lei n. 7.802, de 11-7-89, arts. 14 a 17; Lei n. 8.078, de 11-9-90, arts. $6^{\circ}$, VIII, $14,18,55$ e s., 61 e s.; Lei n. 8.429, de 2-6-92; Lei n. 9.605, de 12-2-98).

(32) Pontes de Miranda, Comentários à Constituição de 1967 com a Emenda n. 1, de 1969, 2ª ed., São Paulo, RT, 1973, t. I, p. 402.

(33) Carlos Maximiliano, Hermenêutica e Aplicação do Direito, $9^{\mathfrak{a}}$ ed., Rio de Janeiro, Forense, 1979, pp. 306, 312.

(34) Dalmo de Abreu Dallari, Constituição e Constituinte, $3^{\text {a }}$ ed., São Paulo, Saraiva, 1986, pp. 14. 


\section{CONSIDERAÇÕES FINAIS E APELO}

Em breves considerações finais, sem qualquer pretensão de esgotar a relevante matéria sobre direito à saúde e problemática dos agrotóxicos, notória, reconhecida e progressivamente vasta, complexa, interdependente e de repercussões crescentes, conclui-se que enorme é o desafio da problemática dos agrotóxicos que, em vez dos benefícios divulgados pelos seus defensores, constituem produtos comprovadamente lesivos ao meio ambiente, aos alimeritos, às bebidas, às águas, com danosos efeitos contra a vida em geral e a saúde da população, tanto nos âmbitos local, distrital e estadual como regional (dois ou mais Estados) e nacional, com reflexos internacionais. Em face da preocupante realidade atual caracterizada por notórias lesões coritra o meio ambiente, a saúde pública e a vida, reportandose às demonstrações e fundamentações constitucionais e legais, considerando a necessidade do real cumprimento das normas jurídicas correlatas, legítimo e reiterado é o nosso APELO à comunidade científico-jurídica nacional, às Universidades públicas e privadas, à Ordem dos Advogados do Brasil, ao Ministério Público, à Advocacia Pública, à Defensoria Pública, aos profissionais da Área da Saúde, às organizações não governamentais, junto aos Poderes Públicos competentes, para as inadiáveis providências, notadamente relacionadas com:

a) O maior rigor na fiscalização, inspeção e aplicação de agrotóxicos, aditivos, de forma permanente, na agricultura, nos alimentos, nas bebidas, nas águas, no arnbiente interno ou externo, com a indicação das doses cientificamente recomendáveis e seguras, as informações claras (nome científico e respectivo nome vulgar ou comum) de todos os aditivos usados nos rótulos, nas embalagens, etiquetas e bulas, nos cartazes de divulgação, tudo de forma evidente que se trata de "alimentos com ou sem agrotóxicos", "alimentos com aditivos", "alimentos irradiados", "alimentos geneticamente modificados", com a definição dos respectivos processos adotados e das substâncias empregaidas, seu teor nutricional e os específicos efeitos colaterais contra a saúde humana.

b) O reexame do art. 10 da Lei n. 8.080, de 19-9-90, perante o Congresso Nacional, para os fins da supressão da inconstitucional expressão "ou eventual" ali erroneamente prevista em matéria de dever constitucional permanente e preventivo em prol da saúde como direito fundamental de todos (nota 10).

c) A revisäo redacional da ementa e das normas dos arts. $1^{\circ}$ e $8^{\circ} \mathrm{da}$ Lei n. 9.294, de 15-7-96, perante o Congresso Nacional, para os fins de substituição da conflitante e inconciliável expressão "defensivos agrícolas" pela expressão científico-constitucional "agrotóxicos" (nota 15). 
d) A reabertura de novos debates, junto ao Congresso Nacional e ao Poder Executivo, para os fins de reapreciação e restabelecimento das normas do art. 57 do Projeto de Lei n. 1.164/91 (transformado na Lei n. 9.605, de 12-2-98), que definem como crime importar ou comercializar agrotóxicos ou produtos tóxicos perigosos ao meio ambiente e à saúde pública de uso proibido em seus país de origem, dentre outras inadiáveis medidas em prol da proteção, da recuperação, da melhoria e da preservação da sadia qualidade ambiental propicia à vida, à segurança e ao estado de pleno bem-estar em todos os setores da sociedade humana presente e futura. 